\title{
Associations between toenail arsenic concentration and dietary factors in a New Hampshire population
}

\author{
Joann F Gruber ${ }^{1,2}$, Margaret R Karagas², Diane Gilbert-Diamond², Pamela J Bagley³, M Scot Zens², Vicki Sayarath², \\ Tracy Punshon ${ }^{1}$, J Steven Morris ${ }^{4}$ and Kathryn L Cottingham ${ }^{1^{*}}$
}

\begin{abstract}
Background: Dietary factors such as folate, vitamin B12, protein, and methionine are important for the excretion of arsenic via one-carbon metabolism in undernourished populations exposed to high levels of arsenic via drinking water. However, the effects of dietary factors on toenail arsenic concentrations in well-nourished populations exposed to relatively low levels of water arsenic are unknown.

Methods: As part of a population-based case-control study of skin and bladder cancer from the USA, we evaluated relationships between consumption of dietary factors and arsenic concentrations in toenail clippings. Consumption of each dietary factor was determined from a validated food frequency questionnaire. We used general linear models to examine the associations between toenail arsenic and each dietary factor, taking into account potentially confounding effects.
\end{abstract}

Results: As expected, we found an inverse association between In-transformed toenail arsenic and consumption of vitamin B12 (excluding supplements) and animal protein. Unexpectedly, there were also inverse associations with numerous dietary lipids (e.g., total fat, total animal fat, total vegetable fat, total monounsaturated fat, total polyunsaturated fat, and total saturated fat). Finally, increased toenail arsenic concentrations were associated with increased consumption of long chain n-3 fatty acids.

Conclusion: In a relatively well-nourished population exposed to relatively low levels of arsenic via water, consumption of certain dietary lipids may decrease toenail arsenic concentration, while long chain n-3 fatty acids may increase toenail arsenic concentration, possibly due to their association with arsenolipids in fish tissue.

Keywords: Arsenic, Epidemiology, Biomarkers, Lipids, Fatty acids, Fish, One-carbon metabolism, Folate

\section{Background}

Exposure to arsenic has been established as a significant human health threat. Chronic exposure to high concentrations of arsenic can cause skin lesions, cancer, developmental toxicity, neurotoxicity, cardiovascular diseases, and other health effects [1,2]. Long-term exposure to lower concentrations of arsenic is also of concern [3-5].

Millions of people worldwide are at risk due to consumption of water contaminated with inorganic arsenic $[6,7]$, and we are all exposed to arsenic via food [1]. For

\footnotetext{
* Correspondence: kathryn.cottingham@dartmouth.edu

'Department of Biological Sciences, Dartmouth College, Hanover, NH 03755, USA

Full list of author information is available at the end of the article
}

example, staple foods such as rice contain appreciable arsenic concentrations, especially of the more toxic, inorganic forms [1,8-13]. Seafood - including fish - is also high in arsenic, but in the less-toxic, organic forms [14]. Recent studies suggest that in the general population, which consumes relatively small concentrations of arsenic in drinking water, diet plays a dominant role in overall exposure [1,8-13].

However, foods also contain factors that are important for one-carbon metabolism, the process by which inorganic arsenic (iAs) is methylated $[15,16]$ and removed from the body. The process of methylation has two steps: first, monomethylarsonic acid (MMA) is formed, and then dimethylarsinic acid (DMA). All three forms

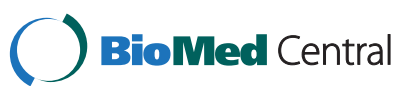


(iAs, MMA, and DMA) are excreted from the body [17-20], but DMA is the most prevalent form of arsenic in urine [21]. DMA is generally believed to be less toxic than iAs, while the trivalent form of the intermediate product MMA may be the most toxic [20]. In populations with nutritional deficiencies and high exposure to inorganic arsenic via drinking water, dietary factors important to complete one-carbon metabolism - including folic acid [18,22,23], vitamin B12 [24], protein [24-26], and methionine $[24,25]$ - appear to facilitate the excretion of arsenic from the body.

Less is known about the impact of dietary factors on the concentrations of arsenic in biologic tissues, such as toenails, over periods of months to years. Arsenic that has not been methylated (i.e., iAs) has a high affinity for keratin, which is found in high concentrations in nails and hair [27]. As a result, iAs can accumulate in hair and nails $[27,28]$, both of which have been used as biomarkers of chronic exposure [29]. For example, toenail arsenic concentrations have been used as a biomarker of exposure both via water and foods [30-32].

We investigated the associations between toenail arsenic concentration and dietary factors in a populationbased study in New Hampshire, USA. Based on previous studies with short-term biomarkers (blood, urine), we hypothesized that the dietary factors important for onecarbon metabolism (including folate, vitamin B12, methionine, and protein) would be inversely associated with toenail arsenic concentration.

\section{Methods}

\section{Study population}

We analyzed existing data from population-based casecontrol studies of bladder and skin cancer conducted among 25 to 74 year old residents of New Hampshire who utilize private groundwater wells as their household water source [33]. Groundwater arsenic concentrations for this population vary spatially, from $<0.0003$ to 180 $\mu \mathrm{g} / \mathrm{L}$ across the state [34,35], creating a natural gradient of exposure to inorganic arsenic via drinking water. The Committee for the Protection of Human Subjects (CPHS) of Dartmouth College approved study materials and protocols (current CPHS \#10107 \& \#11697) and participants provided informed consent according to the approved protocol.

\section{Data collection}

Details of the study design are provided elsewhere [33,36-39]. Briefly, participants were interviewed, usually in their home, to obtain information on sociodemographic factors (e.g., smoking history, drinking water source). To minimize potential reporting biases, interviewers were masked to the case-control status of participants and neither interviewers nor participants were aware of the original study hypotheses [39]. Eighty-five percent of cases and $70 \%$ of controls were interviewed during the bladder cancer study [40], and $82 \%$ of cases and $73 \%$ of controls were interviewed in the skin cancer study [41].

Beginning November 1999 for bladder cancer cases, and August 2000 for skin cancer cases and controls, we asked participants to complete a written, validated, semi-quantitative food frequency questionnaire (FFQ) covering the preceding 12 month period [42,43]. More than $75 \%$ responded to this request. The FFQ asked about the consumption of 121 different items from seven broad categories (dairy, fruits, vegetables, eggs and meat, breads, beverages, and baked goods), as well as dietary supplements (e.g., vitamins), during the past year. Frequency options ranged from never to six or more times a day. Using this instrument, nutrient composition of each food was calculated according to the published methods of Willett and colleagues [44]. Total consumption of each dietary factor was then summed across foods and converted to a daily consumption rate. For vitamins and minerals, we evaluated consumption solely from foods ("without supplements") and consumption including dietary supplements ("with supplements"). All factors examined are listed in Additional File 1.

Finally, participants provided toenail clippings and a sample of household tap water for analysis of total arsenic concentration using previously established protocols $[45,46]$. Overall, over $90 \%$ of participants provided a toenail clipping sample. The majority of subjects $(70 \%)$ provided toenail clippings within 14 days of filling out the FFQ; $91.5 \%$ provided clippings within one year of the FFQ. Further, the vast majority (93.5\%) of toenail clippings were analyzed within 1 year of sample collection. Toenail clippings were analyzed at the University of Missouri Research Reactor Center using standardcomparator instrumental neutron activation analysis [47]. Nail samples were carefully washed prior to analysis to remove external contamination. Drinking water samples were analyzed at the Dartmouth Trace Element Analysis Core following the procedures described in Karagas et al. [45]. Specific quality control measures were taken to ensure the accuracy of laboratory results for both water and toenail samples [45].

\section{Statistical analyses}

Prior to statistical analysis, we normalized data on toenail arsenic concentrations using a natural log transformation. We then excluded subjects who did not meet the caloric thresholds suggested by Willett [48]: 18 men below 800 calories and 13 above 4000 calories, and three women below 500 calories and four above 3500 calories. We also excluded one individual with an extremely high 
toenail arsenic concentration $(7.626 \mu \mathrm{g} / \mathrm{g})$, which was $420 \%$ higher than the next highest concentration.

We evaluated the relation between ln-transformed toenail arsenic and each dietary factor using general linear models (SAS version 9.2), focusing on those factors that had a statistically significant $(\alpha=0.05)$ regression coefficient. For such factors, we confirmed that results were robust to outliers. We explored associations both for the whole population and stratified by arsenic concentration in the subjects' household water supply $(<1 \mu \mathrm{g} / \mathrm{L}$ versus $\geq 1 \mu \mathrm{g} / \mathrm{L}$ ), since $1 \mu \mathrm{g} / \mathrm{L}$ is the concentration above which associations between toenail arsenic and drinking water arsenic concentrations typically emerge [39].

All analyses were conducted both with and without adjustment for potential confounding factors. We retained confounders that were deemed important from previous literature $[45,49,50]$, biological plausibility, and univariate associations. We adjusted for five categorical variables (sex, smoking status [never/ever], season of toenail collection [winter, spring, summer, fall], case-control status [control, bladder cancer, basal cell carcinoma, squamous cell carcinoma], and body mass index (BMI) [normal $\left(<25 \mathrm{~kg} / \mathrm{m}^{2}\right)$, overweight (between $25 \mathrm{~kg} / \mathrm{m}^{2}$ and $30 \mathrm{~kg} / \mathrm{m}^{2}$ ), obese $\left(\geq 30 \mathrm{~kg} / \mathrm{m}^{2}\right)$, missing]) [51] and four continuous variables (age [years], daily intake of water from the household water source $[\mathrm{L} / \mathrm{d}]$, total energy intake $[\mathrm{kcal} / \mathrm{d}]$, and water arsenic concentrations for individuals with water arsenic concentrations $\geq 1 \mu \mathrm{g} / \mathrm{L}$ ). Because seafood is a major source of organic arsenic [14], we also evaluated whether including total seafood consumption in our adjustment model affected our principal findings.

To account for multiple testing across many individual dietary factors, we used the false discovery rate (FDR) procedures implemented in the $\mathrm{R}$ package Q-value [52]. Specifically, we calculated the Q-value, the minimum FDR at which a test may be called statistically significant [53], from the combined list of P-values generated by our two major analyses (100 dietary factors each with a crude and adjusted model). Q-values $\leq 0.05$ were considered statistically significant after correction for multiple testing.

Finally, to help interpret our regression coefficients, we determined the percent change in predicted, backtransformed toenail arsenic concentrations between first quartile and third quartile consumers for each dietary factor. We made predictions using our fully adjusted general linear models, focusing on non-smoking, control subjects with normal BMI whose toenails were collected during the most common season (fall) and whose water arsenic level was $<1 \mu \mathrm{g} / \mathrm{L}$, which was the group containing the majority of participants. Using these categorical predictors, we then made separate predictions for males and females using the mean age, caloric consumption, and water consumption; median arsenic water concentration; and first and third quartile for the dietary factor. By using two separate predictions, we could confirm that patterns of change were generally robust to sex.

\section{Results and discussion}

Our study population included 920 individuals with household water arsenic concentrations ranging from $0.004 \mu \mathrm{g} / \mathrm{L}$ to $158 \mu \mathrm{g} / \mathrm{L}$ (median 0.303), with a median toenail arsenic concentration of $0.085 \mu \mathrm{g} / \mathrm{g}$ (IQR, 0.059 0.132 ; range $0.016-1.816$ ). Household water arsenic concentrations were generally quite low: $77 \%$ of the population had household water $<1 \mu \mathrm{g} / \mathrm{L}$ and $94 \% \mathrm{had}$ water $<10 \mu \mathrm{g} / \mathrm{L}$. For the 213 individuals exposed to $\geq 1 \mu \mathrm{g} / \mathrm{L}$ of arsenic in water, the median water arsenic concentration was still relatively low, $4.154 \mu \mathrm{g} / \mathrm{L}$ (IQR, 2.253 - 10.160; range 1.019 - 158.050). Additional characteristics of the study population are summarized in Table 1. Summary statistics for those dietary factors found to be significantly related to toenail arsenic are provided in Additional File 2.

In preliminary analyses stratified by drinking water exposure $(<1 \mu \mathrm{g} / \mathrm{L}$ vs. $\geq 1 \mu \mathrm{g} / \mathrm{L})$, we did not find meaningful differences in the observed associations between toenail arsenic concentration and dietary factors. Association strength and direction were consistent between strata, but our ability to detect statistically significant associations increased with sample size, such that only the strongest associations were detected in the higherexposure group $(\geq 1 \mu \mathrm{g} / \mathrm{L})$. As such, we report pooled analyses for the entire population below.

\section{Few factors associated with one-carbon metabolism were identified as significant predictors of toenail arsenic}

Based on studies of urinary arsenic metabolites, we hypothesized that there would be negative relationships between toenail arsenic concentration and dietary factors known to be important for one-carbon metabolism (e.g., folic acid, protein, methionine, vitamin B12). However, we found that only animal protein and vitamin B12 without supplement had statistically significant, negative regression coefficients, and estimates of effects on toenail arsenic concentrations from Q1 to Q3 consumers were relatively small $(<7 \%)$ (Table $2 \mathrm{~A})$. In addition, methionine was marginally significantly associated with toenail arsenic after adjustment for potential covariates (slope $(\mathrm{CI})=-0.086(-0.18,0.0063) ; P=0.068)$. These findings were robust to the inclusion of total seafood consumption in the adjustment model (Additional File 3).

One reason we may not have seen strong associations between toenail arsenic concentrations and the dietary factors involved in one-carbon metabolism is that our population had adequate intakes of these dietary factors. Nearly all subjects were at or above the Dietary Reference Intake (DRI) [54] for vitamin B12 (97.1\%) and the majority was at or above the DRIs for total protein 
Table 1 Population characteristics, including information about the variables included in the adjustment model $(\mathbf{n}=\mathbf{9 2 0})$

\begin{tabular}{|c|c|c|c|c|c|c|c|c|}
\hline & \multicolumn{2}{|c|}{$\begin{array}{l}\text { Total population } \\
(n=920)\end{array}$} & \multicolumn{2}{|c|}{$\begin{array}{l}\text { Population with water } \\
{[\mathrm{As}]<1 \mu \mathrm{g} / \mathrm{L}(\mathrm{n}=707)}\end{array}$} & \multicolumn{2}{|c|}{$\begin{array}{l}\text { Population with water [As] } \\
\text { between } 1 \text { and } 10 \mu \mathrm{g} / \mathrm{L}(\mathrm{n}=157)\end{array}$} & \multicolumn{2}{|c|}{$\begin{array}{l}\text { Population with water } \\
{[A s]>10 \mu g / L(n=56)}\end{array}$} \\
\hline A. Continuous variables & \multicolumn{2}{|c|}{ Mean \pm 1SD } & \multicolumn{2}{|c|}{ Mean \pm 1SD } & \multicolumn{2}{|c|}{ Mean \pm 1SD } & \multicolumn{2}{|c|}{ Mean \pm 1 SD } \\
\hline Toenail arsenic $(\mu \mathrm{g} / \mathrm{g})$ & \multicolumn{2}{|c|}{$0.122 \pm 0.136$} & \multicolumn{2}{|c|}{$0.102 \pm 0.096$} & \multicolumn{2}{|c|}{$0.149 \pm 0.154$} & \multicolumn{2}{|c|}{$0.292 \pm 0.297$} \\
\hline Water arsenic $(\mu \mathrm{g} / \mathrm{L})$ & \multicolumn{2}{|c|}{$2.711 \pm 9.978$} & \multicolumn{2}{|c|}{$0.269 \pm 0.225$} & \multicolumn{2}{|c|}{$3.806 \pm 2.498$} & \multicolumn{2}{|c|}{$30.467 \pm 27.942$} \\
\hline Age (years) & \multicolumn{2}{|c|}{$61.0 \pm 10.0$} & \multicolumn{2}{|c|}{$61.1 \pm 10.1$} & \multicolumn{2}{|c|}{$60.5 \pm 9.9$} & \multicolumn{2}{|c|}{$61.7 \pm 10.1$} \\
\hline $\begin{array}{l}\text { Water consumption } \\
\text { from household supply (L/d) }\end{array}$ & \multicolumn{2}{|c|}{$1.11 \pm 0.77$} & \multicolumn{2}{|c|}{$1.11 \pm 0.76$} & \multicolumn{2}{|c|}{$1.07 \pm 0.75$} & \multicolumn{2}{|c|}{$1.17 \pm 0.94$} \\
\hline Energy intake (kcal/d) & \multicolumn{2}{|c|}{$1919.1 \pm 630.1$} & \multicolumn{2}{|c|}{$1907.3 \pm 633.8$} & \multicolumn{2}{|c|}{$1934.8 \pm 600.9$} & \multicolumn{2}{|c|}{$2024.6 \pm 662.1$} \\
\hline B. Categorical variables & $\mathbf{n}$ & $\%$ & $\mathbf{n}$ & $\%$ & $\mathbf{n}$ & $\%$ & $\mathbf{n}$ & $\%$ \\
\hline \multicolumn{9}{|l|}{ Sex } \\
\hline Female & 364 & 39.6 & 280 & 39.6 & 66 & 42.0 & 18 & 32.1 \\
\hline Male & 556 & 60.4 & 427 & 60.4 & 91 & 58.0 & 38 & 67.9 \\
\hline \multicolumn{9}{|l|}{ Smoking status } \\
\hline Never smoked & 298 & 32.4 & 224 & 31.7 & 57 & 36.3 & 17 & 30.4 \\
\hline Has smoked & 622 & 67.6 & 483 & 68.3 & 100 & 63.7 & 39 & 69.6 \\
\hline Season in which the toenail sar & mple & collected & & & & & & \\
\hline Winter & 186 & 20.2 & 142 & 20.1 & 30 & 19.1 & 14 & 25.0 \\
\hline Spring & 182 & 19.8 & 144 & 20.4 & 32 & 20.4 & 6 & 10.7 \\
\hline Summer & 268 & 29.1 & 191 & 27.0 & 52 & 33.1 & 25 & 44.6 \\
\hline Fall & 284 & 30.9 & 230 & 32.5 & 43 & 27.4 & 11 & 19.6 \\
\hline Case-control Status & & & & & & & & \\
\hline Control & 227 & 24.7 & 179 & 25.3 & 33 & 21.0 & 15 & 26.8 \\
\hline Bladder cancer & 275 & 29.9 & 206 & 29.1 & 45 & 28.7 & 24 & 42.9 \\
\hline Basal cell skin cancer & 214 & 23.3 & 162 & 22.9 & 40 & 25.5 & 12 & 21.4 \\
\hline Squamous cell skin cancer & 204 & 22.2 & 160 & 22.6 & 39 & 24.8 & 5 & 8.9 \\
\hline Body mass index & & & & & & & & \\
\hline Normal $\left(<25 \mathrm{~kg} / \mathrm{m}^{2}\right)$ & 164 & 17.8 & 119 & 16.8 & 37 & 23.8 & 8 & 14.3 \\
\hline $\begin{array}{l}\text { Overweight } \\
\left(\geq 25 \mathrm{~kg} / \mathrm{m}^{2} \&<30 \mathrm{~kg} / \mathrm{m}^{2}\right)\end{array}$ & 176 & 19.1 & 142 & 20.1 & 28 & 17.8 & 6 & 10.7 \\
\hline Obese $\left(\geq 30 \mathrm{~kg} / \mathrm{m}^{2}\right)$ & 73 & 7.9 & 56 & 7.9 & 14 & 8.9 & 3 & 5.4 \\
\hline Missing & 507 & 55.1 & 390 & 55.2 & 78 & 49.7 & 39 & 69.6 \\
\hline
\end{tabular}

(87.2\%) and folate (69.1\%). This study was conducted after folic acid fortification of enriched grain products in the USA (phased in from 1996-1998 [55]), which likely helped contribute to adequate folate intake.

Alternatively, the factors affecting toenail arsenic concentrations, a long-term biomarker of arsenic exposure, may differ from the factors affecting short-term detoxification and excretion, as indicated by urinary arsenic concentrations. A study comparing long and short term biomarkers in both well-nourished and poorly nourished populations, with drinking water exposures ranging from very low $(<1 \mu \mathrm{g} / \mathrm{L})$ to $>10 \mu \mathrm{g} / \mathrm{L}$ (the current USEPA drinking water standard) would help to identify which dietary factors have the greatest effect on toenail arsenic concentration.

\section{Many dietary lipids were inversely associated with} toenail arsenic

Of the 20 dietary factors inversely associated with lntransformed toenail arsenic, 16 were dietary lipids (Table 2A) and these findings were robust to the inclusion of total seafood consumption in our adjustment model (Additional File 3). Ten of these factors remained significant after correction for multiple testing: total fat (Figure 1A), total monounsaturated fat, total polyunsaturated fat, total saturated fat, and several individual fatty acids (Table 2A). The magnitudes of effect varied, ranging from relatively small (4-8\%) for several of the fatty acids to quite large (15-20\%) for total fat (Table 2A).

It is not clear why so many dietary lipids were negatively associated with toenail arsenic in this study 
Table 2 Dietary factors that were significantly associated with toenail arsenic concentration (bold) ${ }^{\mathrm{a}}$ : Q-values $\leq 0.05$ are noted with a * next to the $P$ value

\begin{tabular}{|c|c|c|c|c|c|c|}
\hline \multirow[t]{3}{*}{ Variable } & \multicolumn{6}{|l|}{ Regression slopes } \\
\hline & \multicolumn{2}{|l|}{ Crude $(n=920)$} & \multicolumn{2}{|l|}{ Adjusted $^{\mathrm{a}}(\mathrm{n}=914)$} & \multirow[b]{2}{*}{$\begin{array}{l}\text { \% change } \\
\text { Q1-Q3 } \\
\text { males }\end{array}$} & \multirow[b]{2}{*}{$\begin{array}{l}\text { \% change } \\
\text { Q1-Q3 } \\
\text { females }\end{array}$} \\
\hline & $\beta(95 \% \mathrm{Cl})$ & $P$ value & $\beta(95 \% \mathrm{Cl})$ & $P$ value & & \\
\hline \multicolumn{7}{|l|}{ A. Negative associations } \\
\hline \multicolumn{7}{|l|}{ Dietary lipids } \\
\hline Total fat (g) & $-1.5 \mathrm{E}-03(-3.0 \mathrm{E}-03,3.5 \mathrm{E}-05)$ & 0.056 & $-5.8 \mathrm{E}-03(-8.4 \mathrm{E}-03,-3.2 \mathrm{E}-03)$ & $<0.001^{*}$ & -20.6 & -16.4 \\
\hline Animal fat (g) & $-1.8 \mathrm{E}-03(-4.2 \mathrm{E}-03,5.7 \mathrm{E}-04)$ & 0.14 & $-4.2 \mathrm{E}-03(-7.2 \mathrm{E}-03,-1.2 \mathrm{E}-03)$ & 0.006 & -9.3 & -7.1 \\
\hline Vegetable fat (g) & $-2.4 \mathrm{E}-03(-5.1 \mathrm{E}-03,3.0 \mathrm{E}-04)$ & 0.081 & $-4.9 \mathrm{E}-03(-8.5 \mathrm{E}-03,-1.3 \mathrm{E}-03)$ & 0.008 & -10.6 & -8.7 \\
\hline \multicolumn{7}{|l|}{ Total unsaturated fat } \\
\hline Total monounsaturated fat (g) & $-3.6 \mathrm{E}-03(-7.4 \mathrm{E}-03,1.0 \mathrm{E}-04)$ & 0.057 & $-1.2 \mathrm{E}-02(-1.8 \mathrm{E}-02,-5.6 \mathrm{E}-03)$ & $<0.001^{*}$ & -17.0 & -14.1 \\
\hline Palmitoleic fatty acid (g) & $-4.4 \mathrm{E}-02(-1.1 \mathrm{E}-01,2.1 \mathrm{E}-02)$ & 0.18 & $-1.0 \mathrm{E}-01(-1.8 \mathrm{E}-01,-1.9 \mathrm{E}-02)$ & 0.016 & -8.1 & -6.8 \\
\hline Oleic fatty acid (g) & $-4.2 \mathrm{E}-03(-8.3 \mathrm{E}-03,-7.6 \mathrm{E}-05)$ & 0.046 & $-1.3 \mathrm{E}-02(-2.0 \mathrm{E}-02,-6.4 \mathrm{E}-03)$ & $<0.001^{*}$ & -17.1 & -13.5 \\
\hline Total polyunsaturated fat (g) & $-5.5 \mathrm{E}-03(-1.3 \mathrm{E}-02,2.1 \mathrm{E}-03)$ & 0.16 & $-1.8 \mathrm{E}-02(-2.9 \mathrm{E}-02,-7.3 \mathrm{E}-03)$ & $0.001^{*}$ & -13.2 & -10.2 \\
\hline Total n-6 fatty acids ${ }^{\mathrm{d}}(\mathrm{g})$ & $-6.1 \mathrm{E}-03(-1.4 \mathrm{E}-02,2.2 \mathrm{E}-03)$ & 0.15 & $-1.8 \mathrm{E}-02(-2.9 \mathrm{E}-02,-6.5 \mathrm{E}-03)$ & $0.002 *$ & -11.7 & -9.7 \\
\hline Linoleic fatty acid (g) & $-7.1 \mathrm{E}-03(-1.6 \mathrm{E}-02,1.6 \mathrm{E}-03)$ & 0.11 & $-2.0 \mathrm{E}-02(-3.2 \mathrm{E}-02,-8.7 \mathrm{E}-03)$ & $<0.001^{*}$ & -13.0 & -10.2 \\
\hline Linolenic fatty acid (g) & $-3.8 \mathrm{E}-02(-1.2 \mathrm{E}-01,4.1 \mathrm{E}-02)$ & 0.35 & $-1.6 \mathrm{E}-01$ (-2.7E-01, -5.4E-02) & $0.003^{*}$ & -10.8 & -9.3 \\
\hline Arachadonic fatty acid (g) & $-4.3 \mathrm{E}-01(-1.1 \mathrm{E}+00,2.1 \mathrm{E}-01)$ & 0.19 & $-6.8 \mathrm{E}-01(-1.3 \mathrm{E}+00,-4.0 \mathrm{E}-02)$ & 0.037 & -5.3 & -4.7 \\
\hline Total saturated fat (g) & $-3.5 \mathrm{E}-03(-7.5 \mathrm{E}-03,4.8 \mathrm{E}-04)$ & 0.084 & $-1.0 \mathrm{E}-02(-1.6 \mathrm{E}-02,-4.5 \mathrm{E}-03)$ & $<0.001^{*}$ & -13.4 & -10.8 \\
\hline Lauric fatty acid (g) & $-1.2 \mathrm{E}-01(-2.3 \mathrm{E}-01,-4.5 \mathrm{E}-04)$ & 0.049 & $-1.7 \mathrm{E}-01(-2.9 \mathrm{E}-01,-4.8 \mathrm{E}-02)$ & 0.006 & -6.5 & -5.1 \\
\hline Palmitic fatty acid (g) & $-6.7 \mathrm{E}-03(-1.4 \mathrm{E}-02,8.2 \mathrm{E}-04)$ & 0.081 & $-2.2 \mathrm{E}-02(-3.4 \mathrm{E}-02,-1.1 \mathrm{E}-02)$ & $<0.001^{*}$ & -15.5 & -12.8 \\
\hline Stearic fatty acid (g) & $-1.8 \mathrm{E}-02(-3.3 \mathrm{E}-02,-3.0 \mathrm{E}-03)$ & 0.018 & $-4.3 \mathrm{E}-02(-6.5 \mathrm{E}-02,-2.1 \mathrm{E}-02$ & $<0.001^{*}$ & -15.6 & -12.8 \\
\hline \multicolumn{7}{|l|}{ Steroid } \\
\hline Cholesterol (mg) & $-2.9 \mathrm{E}-04(-6.3 \mathrm{E}-04,3.9 \mathrm{E}-05)$ & 0.084 & $-5.0 \mathrm{E}-04(-8.7 \mathrm{E}-04,-1.4 \mathrm{E}-04)$ & 0.007 & -7.3 & -6.2 \\
\hline \multicolumn{7}{|l|}{ Protein } \\
\hline Animal protein (g) & $-7.3 \mathrm{E}-04$ (-2.7E-03, 1.3E-03) & 0.47 & $-2.6 \mathrm{E}-03(-5.0 \mathrm{E}-03,-1.5 \mathrm{E}-04)$ & 0.037 & -6.6 & -6.4 \\
\hline \multicolumn{7}{|l|}{ Vitamins } \\
\hline Retinole $^{e}(I U)$ & $-3.2 \mathrm{E}-05$ (-5.7E-05, -7.3E-06) & 0.011 & $-2.9 \mathrm{E}-05(-5.2 \mathrm{E}-05,-6.1 \mathrm{E}-06)$ & 0.013 & -3.8 & -3.2 \\
\hline Vitamin $\mathrm{B} 12^{\mathrm{e}}(\mu \mathrm{g})$ & $-8.5 \mathrm{E}-03(-1.6 \mathrm{E}-02,-1.1 \mathrm{E}-03)$ & 0.024 & $-7.6 \mathrm{E}-03(-1.5 \mathrm{E}-02,-5.2 \mathrm{E}-04)$ & 0.035 & -3.1 & -2.3 \\
\hline \multicolumn{7}{|l|}{ Plant-compounds } \\
\hline Beta cryptoxanthin $(\mu \mathrm{g})$ & $-3.2 \mathrm{E}-04(-6.6 \mathrm{E}-04,2.9 \mathrm{E}-05)$ & 0.072 & $-3.7 \mathrm{E}-04(-6.9 \mathrm{E}-04,-5.1 \mathrm{E}-05)$ & 0.023 & -6.1 & -6.4 \\
\hline \multicolumn{7}{|l|}{ B. Positive associations } \\
\hline \multicolumn{7}{|l|}{ Dietary lipids } \\
\hline \multicolumn{7}{|l|}{ Total unsaturated fat } \\
\hline \multicolumn{7}{|l|}{ Polyunsaturated fat } \\
\hline $\begin{array}{l}\text { n-3 Fatty acids } \\
\left(\mathrm{EPA}^{\mathrm{f}}, \mathrm{DPA}^{\mathrm{g}}, \mathrm{DHA}^{\mathrm{h}}\right)(\mathrm{g})\end{array}$ & & 0.035 & 1.4E-01 (4.6E-04, 2.8E-01) & 0.049 & 3.5 & 3.4 \\
\hline $\begin{array}{l}\text { n-3 Fatty acidsi } \\
\text { (EPA \& DHA) (g) }\end{array}$ & $1.8 \mathrm{E}-01$ (1.3E-02, 3.4E-01) & 0.034 & $1.5 \mathrm{E}-01$ (1.6E-03, 3.0E-01) & 0.048 & 3.4 & 3.6 \\
\hline EPA (g) & 4.7E-01 (9.2E-02, 8.4E-01) & 0.015 & 4.0E-01 (5.9E-02, 7.4E-01) & 0.022 & 3.7 & 3.7 \\
\hline DPA (g) & $2.9 \mathrm{E}+00(4.4 \mathrm{E}-01,5.3 \mathrm{E}+00)$ & 0.021 & $2.2 \mathrm{E}+00(-6.7 \mathrm{E}-02,4.4 \mathrm{E}+00)$ & 0.057 & 4.5 & 4.5 \\
\hline \multicolumn{7}{|l|}{ Elements } \\
\hline Manganese $^{\mathrm{e}}(\mathrm{mg})$ & 3.9E-03 (6.8E-05, 7.7E-03) & 0.046 & $5.1 \mathrm{E}-03(-2.0 \mathrm{E}-03,1.2 \mathrm{E}-02)$ & 0.16 & 9.9 & 9.6 \\
\hline \multicolumn{7}{|l|}{ Alcohols } \\
\hline Ethanol (g) & $6.0 \mathrm{E}-03(3.1 \mathrm{E}-03,8.8 \mathrm{E}-03)$ & $<0.001^{*}$ & $6.6 \mathrm{E}-03(4.0 \mathrm{E}-03,9.2 \mathrm{E}-03)$ & $<0.001^{*}$ & 10.0 & 3.2 \\
\hline
\end{tabular}




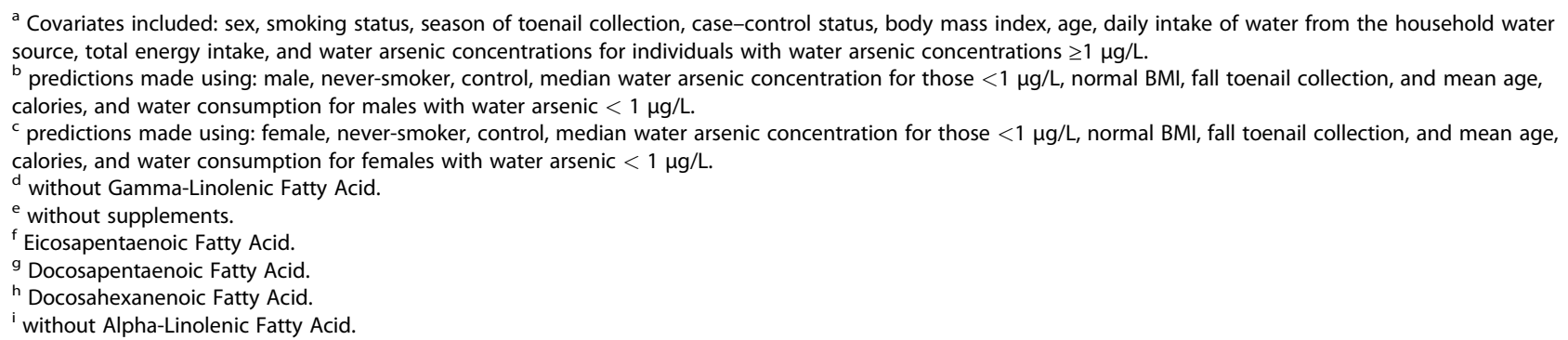

population. Until very recently, little research had been published on how dietary lipids affect arsenic metabolism; this past research shows either no effect or a detrimental effect of fats on the ability to methylate and excrete arsenic from the body (which presumably would result in a positive association with toenail arsenic concentrations). No mention is made of dietary lipids in many previous studies in humans [18,22-25], perhaps because they focused on poorly nourished populations in Bangladesh. Similarly, Steinmaus et al. [26] reported that fat, saturated fat, oleic fatty acid, linoleic fatty acid, and cholesterol consumption were unrelated to the proportions of urinary arsenic metabolites in a population in the western United States. In contrast, Basu et al. [56] found that animal fat intake was the strongest predictor of the percent MMA in urinary arsenic in a population in West Bengal, India. They hypothesize this finding is likely due to a reduction in the second step of methylation (MMA to DMA) rather than an increase in the first methylation step (iAs to MMA) [56]. Thus, our finding is novel.
From a physiological perspective it is conceivable that fat could form a complex with arsenic during digestion, inhibiting its absorption into the bloodstream and thus resulting in both decreased exposure and decreased toenail arsenic concentration. For example, lipid particles associated with proteins can interact with arsenic [57], which could provide an alternative mechanism for detoxification. Another possibility is that certain dietary lipids may have higher affinities for arsenic-containing compounds, preventing them from concentrating in toenails. Another plausible explanation is that foods with higher fat content contribute relatively less dietary arsenic compared to carbohydrate- and protein-rich foods (such as rice and fish) resulting in negative correlations in our energy adjusted analysis.

Further investigation is needed to determine whether there are biological mechanisms to account for why short-term and long-term biomarkers appear to produce different results regarding the effect of fats on arsenic biomarkers and whether the nutritional status of the
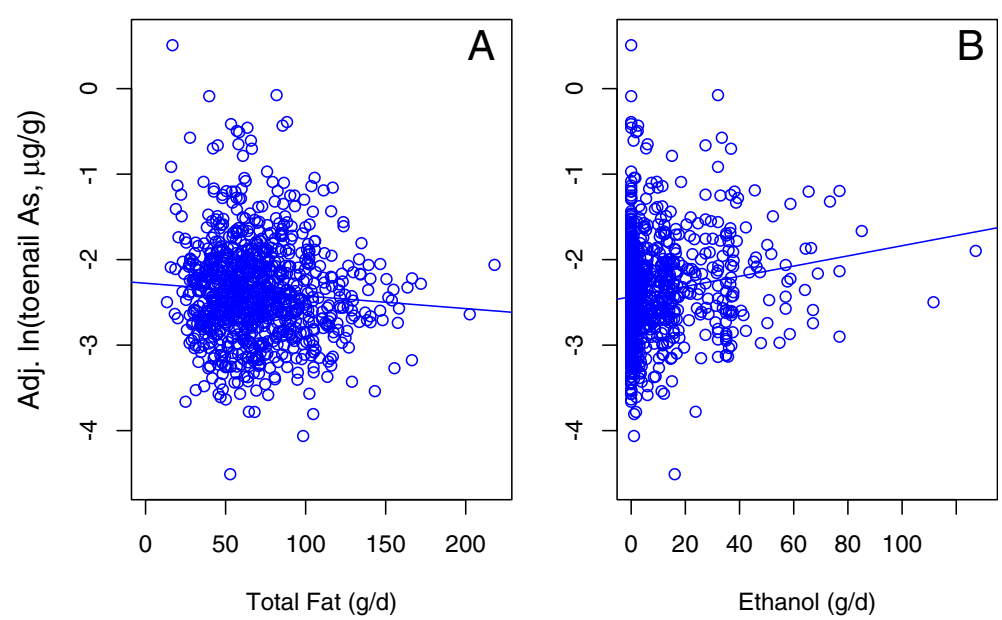

Figure 1 Association of toenail arsenic concentration with total fat and alcohol in our case-control study population. The adjusted, Intransformed toenail arsenic concentration (mean plus the residuals from the adjustment model described in the text) varies inversely with (A) total fat consumption $(\mathrm{g} / \mathrm{d})$ and $(\mathbf{B})$ positively with ethanol consumption $(\mathrm{g} / \mathrm{d})$. The blue line in each panel represents the least squares regression between the predictor and response variable, and so differs slightly from the lines fit in the full general linear model. 
individual plays a role in determining such different responses.

\section{Fatty acids typically found in fish oils were positively associated with toenail arsenic concentration}

In contrast to the relationships with other dietary lipids, we found that intake of long chain n-3 polyunsaturated fatty acids, both individually and combined, were positively associated with toenail arsenic concentrations (Table 2B). Although magnitudes of effect were small (resulting in a 3-5\% change in predicted toenail arsenic concentrations) and none of these variables was significantly associated with toenail arsenic after correction for multiple testing, we find these associations noteworthy. Eicosapentaenoic fatty acid (EPA) and docosahexaenoic fatty acid (DHA) are found in large quantities in fish oils [58,59] and docosapentaenoic fatty acid (DPA) is a biochemical intermediary between these forms [60]. Fish have some of the highest total arsenic concentrations in food $[61,62]$. This arsenic is expected to be predominantly in non-toxic organic forms such as arsenobetaine, which is not metabolized [50] and is excreted from the body relatively quickly [14]. However, fish also contain arsenolipids [63-66]; for example, cod-liver oil contains six arsenolipids immediately alongside long chain n-3 fatty acids [65]. Arsenolipids can be metabolized [64], which may release arsenic that can circulate and accumulate in toenails. We speculate that the positive associations between toenail arsenic concentrations and long chain n-3 fatty acids may be markers for a true underlying relationship between arsenolipids and toenail arsenic, a hypothesis supported by the fact that these associations were not detected when total seafood consumption was included in our adjustment model (Additional File 3). However, further studies are needed to confirm this relationship.

\section{Alcohol was positively associated with toenail arsenic} Consistent with previous epidemiological $[32,67]$ and modeling [13] studies, we found strong positive associations between toenail arsenic concentrations and consumption of ethanol (Figure 1B, Table 2B), which remained significant after correction for multiple testing and after adjustment for total seafood consumption. This finding is also consistent with previous research on other biomarkers of arsenic exposure [68]. Among individuals exposed to varying concentrations of arsenic in drinking water, consumers of one or more alcoholic beverages per week had significantly higher proportions of inorganic urinary arsenic species when compared to individuals who consumed no alcoholic beverages [68]. This finding could be explained by alcohol's ability to inhibit methionine synthase, which is important for arsenic metabolism [69]. Impeded metabolism of arsenic could also explain why toenail arsenic concentration was positively associated with alcohol consumption. In addition, alcoholic beverages such as beer and wine may themselves be a source of arsenic exposure [70], due to contamination of key ingredients.

\section{Miscellaneous dietary factors were associated with toenail arsenic}

There were three dietary factors that had significant regression coefficients that did not remain significant after correction for multiple testing: retinol without supplements (negatively associated), beta cryptoxanthin (negatively associated), and manganese without supplements (positively associated). These relationships were likely a result of testing 100 dietary factors, since we know of no scientific reason that these dietary factors would be related to toenail arsenic.

\section{Potential limitations}

Although toenails have limitations as biomarkers [29], these limitations likely did not affect our results. Orloff et al. (2009) identified three major problems with nails: (1) variability in growth rate, and thus the time period indicated by arsenic concentrations in nail clippings, (2) external contamination, and (3) inconsistent protocols for collection and analysis. Because our dietary information is averaged across a year, and our toenail clippings represent ca. 12 months of growth [71], we believe that the time scales for the predictor and response variables are matched appropriately. Contamination was minimized by having toenails collected immediately after bathing and scraping, and by sonicating nails in the laboratory prior to analysis [72]. Finally, all nails were analyzed in the same way, creating internal consistency within the study, even if we cannot make direct comparisons of toenail arsenic concentrations to other published studies [29].

Of greater relevance to the generality of our conclusions are the imprecision with which dietary factors were assessed and the inclusion of cancer patients among the study participants. First, our estimates of dietary factor consumption are likely to be less precise than our estimates of toenail arsenic concentration, violating one of the assumptions of general linear models. For example, recall bias could have affected the responses to the FFQ, potentially underestimating consumption of 'unhealthy' diet items (e.g., fatty foods) and overestimating consumption of 'healthy' items [73]. In addition, both the rate of intake of food items and the levels of dietary factors in foods can vary greatly over a one-year period, making it difficult to precisely estimate consumption of specific dietary factors. However, these errors would tend to bias results in favor of not detecting significant relationships, due to the so-called "errors in variables" 
problem [74]. In addition, while we adjusted for case status, many of the participants were cancer cases, which could affect the generalizability of our finding since it is plausible that these individuals process arsenic differently than non-cancer cases.

\section{Conclusion}

This study tested the hypothesis that the dietary factors associated with toenail arsenic concentrations in wellnourished populations exposed to relatively low levels of water arsenic would be similar to the dietary factors associated with urinary arsenic concentrations in malnourished, highly exposed populations. Our findings do not support this hypothesis. Instead, several dietary lipids were inversely related to toenail arsenic concentration in our population, possibly because they inhibit the absorption of arsenic or its accumulation in toenails. However, long chain n-3 fatty acids (EPA, DPA, and DHA) were positively associated with toenail arsenic, potentially due to the association between these longchain n-3 fatty acids and arsenolipids in fish tissue. Thus, our data suggest an association between dietary lipids and arsenic concentrations in biologic tissue.

\section{Additional files}

Additional file 1: List of all dietary factors analyzed. This table provides a list of all the dietary factors that were analyzed in this analysis. Additional file 2: Quartiles of consumption of significant dietary factors. This table provides summary statistics on the consumption of significant dietary factors.

Additional file 3: Dietary factors significantly associated (bold) with toenail arsenic with and without adjustment for seafood consumption. This table provides a comparison of our presented results with results that also included adjustment for total seafood consumption.

\section{Competing interests}

The authors declare that they have no competing interests.

\section{Authors' contributions}

JFG and KLC designed the research, conducted analyses, and drafted and critically revised the manuscript. MRK conceived and designed the study, obtained funding, collected and interpreted data, and critically revised the manuscript. DGD, PJB, and TP provided interpretations of results and critically revised the manuscript. MSZ collected data and conducted initial analyses, VS coordinated data collection and provided technical support, and JSM collected data and provided comments on the manuscript. All authors have read and approved the final manuscript.

\section{Funding}

This work was supported in part by grants P20 ES018175 and P42 ES007373 from the National Institute of Environmental Health Sciences (NIEHS), US National Institutes of Health (NIH); grant CA57494 from the National Cancer Institute (NCI), $\mathrm{NIH}$; and RD-83459901-0 from the US Environmental Protection Agency (USEPA). These agencies were not involved in the design and conduct of the study; the collection, management, analysis, and interpretation of the data; the writing of the report; or the decision to submit for publication. Its contents are solely the responsibility of the authors and do not necessarily represent the official views of the NIEHS, NCl, $\mathrm{NIH}$, or USEPA. Further, USEPA does not endorse the purchase of any commercial products or services mentioned in the publication.

\section{Acknowledgments}

We thank Adam Strom for programming assistance, and Ryan Akrami, Dr. Natasha Grotz, and Dr. Lee Witters for editing assistance. We also thank Megan Hall, Craig Steinmaus, Melissa Slotnick, and Tejo Prakash N Nagaraja for their helpful reviews of an earlier version of the manuscript.

\section{Author details}

'Department of Biological Sciences, Dartmouth College, Hanover, NH 03755, USA. ${ }^{2}$ Section of Biostatistics and Epidemiology, Dartmouth Medical School, Hanover, NH 03755, USA. ${ }^{3}$ Biomedical Libraries, Dartmouth College, Hanover, $\mathrm{NH}$ 03755, USA. ${ }^{4}$ Research Reactor Center, University of Missouri and Harry S Truman Memorial Veterans Hospital, Columbia, MO 65211, USA.

Received: 2 September 2011 Accepted: 29 June 2012

Published: 29 June 2012

\section{References}

1. European Food Safety Authority: EPFA Panel on contaminants in the food chain (CONTAM): scientific opinion on arsenic in food. EFSA Journal 2009, 7:1351-1548.

2. IARC: Some drinking-water disinfectants and contaminants, including arsenic. In IARC Monographs on the Evaluation of Carcinogenic Risks to Humans. Edited by Northrup Linda, Mitchell Jane. France: IRAC Press; 2004 [Straif K (Section Head): IRAC Monographs, vol 84.].

3. Heck JE, Andrew AS, Onega T, Rigas JR, Jackson BP, Karagas MR, Duell EJ: Lung cancer in a US population with low to moderate arsenic exposure. Environ Health Perspect 2009, 117:1718-1723.

4. Karagas MR, Stukel TA, Tosteson TD: Assessment of cancer risk and environmental levels of arsenic in New Hampshire. Int J Hyg Environ Health 2002, 205:85-94.

5. Lisabeth LD, Ahn HJ, Chen JJ, Sealy-Jefferson S, Burke JF, Meliker JR: Arsenic in drinking water and stroke hospitalizations in Michigan. Stroke 2010, 41:2499-2504.

6. Argos M, Rathouz PJ, Pierce BL, Kalra T, Parvez F, Slavkovich V, Ahmed A, Chen Y, Ahsan H: Dietary B vitamin intakes and urinary total arsenic concentration in the Health Effects of Arsenic Longitudinal Study (HEALS) cohort, Bangladesh. Eur J Nutr 2010, 49:473-481.

7. Meharg AA: Venomous earth: How arsenic caused the world's worst mass poisoning. Houndsmill, England: Macmillan; 2005.

8. Kile ML, Houseman EA, Breton CV, Smith T, Quamruzzaman Q, Rahman M, Mahiuddin G, Christiani DC: Dietary arsenic exposure in Bangladesh. Environ Health Perspect 2007, 115:889-893.

9. Zavala YJ, Duxbury JM: Arsenic in rice: I. Estimating normal levels of total arsenic in rice grain. Environ Sci Technol 2008, 42:3856-3860.

10. Zavala YJ, Gerads R, Gürleyük H, Duxbury JM: Arsenic in rice: II. Arsenic speciation in USA grain and implications for human health. Environ Sci Technol 2008, 42:3861-3866.

11. Meliker JR, Franzblau A, Slotnick MJ, Nriagu JO: Major contributors to inorganic arsenic intake in southeastern Michigan. Int J Hyg Environ Health 2006, 209:399-411.

12. Signes-Pastor AJ, Mitra K, Sarkhel S, Hobbes M, Burlo F, de Groot WT, Carbonell-Barrachina AA: Arsenic speciation in food and estimation of the dietary intake of inorganic arsenic in a rural village of West Bengal, India. J Agric Food Chem 2008, 56:9469-9474.

13. Xue J, Zartarian V, Wang SW, Liu SV, Georgopoulos P: Probabilistic modeling of dietary arsenic exposure and dose and evaluation with 2003-2004 NHANES data. Environ Health Perspect 2010, 118:345-350.

14. Francesconi KA: Arsenic species in seafood: Origin and human health implications. Pure Appl Chem 2010, 82:373-381.

15. Challenger F, Leeds E: Biological methylation. Chem Rev 1945, 36:315-361.

16. Hayakawa T, Kobayashi Y, Cui X, Hirano S: A new metabolic pathway of arsenite: arsenic-glutathione complexes are substrates for human arsenic methyltransferase Cyt19. Arch Toxicol 2005, 79:183-191.

17. Vahter M: Effects of arsenic on maternal and fetal health. Annu Rev Nutr 2009, 29:381-399.

18. Gamble MV, Liu X, Ahsan H, Pilsner JR, llievski V, Slavkovich V, Parvez F, Chen Y, Levy D, Factor-Litvak P, Graziano JH: Folate and arsenic metabolism: a double-blind, placebo-controlled folic acidsupplementation trial in Bangladesh. Am J Clin Nutr 2006, 84:1093-1101.

19. Kenyon EM, Hughes MF: A concise review of the toxicity and carcinogenicity of dimethylarsinic acid. Toxicology 2001, 160:227-236. 
20. Petrick JS, Ayala-Fierro F, Cullen WR, Carter DE, Aposhian VH: Monomethylarsonous acid (MMAIII) is more toxic than arsenite in Chang human hepatocytes. Toxicol Appl Pharmacol 2000, 163:203-207.

21. Vahter M, Concha G: Role of metabolism in arsenic toxicity. Pharmacol Toxicol 2001, 89:1-5.

22. Gamble MV, Liu X, Slavkovich V, Pilsner JR, Ilievski V, Factor-Litvak P, Levy D, Alam S, Islam M, Parvez F: Folic acid supplementation lowers blood arsenic. Am J Clin Nutr 2007, 86:1202-1209.

23. Gamble MV, Liu X, Ahsan H, Pilsner JR, Ilievski V, Slavkovich V, Parvez F, Levy D, Factor-Litvak P, Graziano JH: Folate, homocysteine, and arsenic metabolism in arsenic-exposed individuals in Bangladesh. Environ Health Perspect 2005, 113:1683-1688.

24. Heck JE, Gamble MV, Chen Y, Graziano JH, Slavkovich V, Parvez F, Baron JA, Howe GR, Ahsan $\mathrm{H}$ : Consumption of folate-related nutrients and metabolism of arsenic in Bangladesh. Am J Clin Nutr 2007, 85:1367-1374.

25. Heck JE, Nieves JW, Chen Y, Parvez F, Brandt-Rauf PW, Graziano JH, Slavkovich $\mathrm{V}$, Howe GR, Ahsan H: Dietary intake of methionine, cysteine, and protein and urinary arsenic excretion in Bangladesh. Environ Health Perspect 2009, 117:99-104.

26. Steinmaus C, Carrigan K, Kalman D, Atallah R, Yuan Y, Smith AH: Dietary intake and arsenic methylation in a U.S. population. Environ Health Perspect 2005, 113:1153-1159.

27. National Research Council (US): Subcommittee on Arsenic in Drinking Water: Arsenic in drinking water. Washington, DC: National Academies Press; 1999.

28. Button M, Jenkin GRT, Harrington CF, Watts MJ: Human toenails as a biomarker of exposure to elevated environmental arsenic. J Environ Monit 2009, 11:610-617.

29. Orloff K, Mistry K, Metcalf S: Biomonitoring for environmental exposures to arsenic. J toxicol Environ Health, Pt B 2009, 12:509-524.

30. Slotnick MJ, Meliker JR, AvRuskin GA, Ghosh D, Nriagu JO: Toenails as a biomarker of inorganic arsenic intake from drinking water and foods. Journal of Toxicology and Environmental Health Part A 2007, 70:148-158.

31. Slotnick MJ, Nriagu JO: Validity of human nails as a biomarker of arsenic and selenium exposure: a review. Environ Res 2006, 102:125-139.

32. MacIntosh DL, Williams PL, Hunter DJ, Sampson LA, Morris SC, Willett WC, Rimm EB: Evaluation of a food frequency questionnaire-food composition approach for estimating dietary intake of inorganic arsenic and methylmercury. Cancer Epidemiol Biomarkers Prev 1997 6:1043-1050.

33. Karagas MR, Tosteson TD, Blum J, Morris JS, Baron JA, Klaue B: Design of an epidemiologic study of drinking water arsenic exposure and skin and bladder cancer risk in a U.S. population. Environ Health Perspect 1998, 106:1047-1050.

34. Peters SC, Blum JD, Klaue B, Karagas MR: Arsenic occurrence in New Hampshire drinking water. Environ Sci Technol 1999, 33:1328-1333.

35. Ayotte JD, Nolan BT, Nuckols JR, Cantor KP, Robinson GR Jr, Baris D, Hayes L, Karagas M, Bress W, Silverman DT: Modeling the probability of arsenic in groundwater in New England as a tool for exposure assessment. Environ Sci Technol 2006, 40:3578-3585.

36. Applebaum KM, Karagas MR, Hunter DJ, Catalano PJ, Byler SH, Morris S, Nelson $\mathrm{HH}$ : Polymorphisms in nucleotide excision repair genes, arsenic exposure, and non-melanoma skin cancer in New Hampshire. Environ Health Perspect 2007, 115:1231-1236.

37. Brinkman MT, Karagas MR, Zens MS, Schned A, Reulen RC, Zeegers MP: Minerals and vitamins and the risk of bladder cancer: results from the New Hampshire Study. Cancer Causes and Control 2010, 21:609-619.

38. Fortuny J, Kogevinas M, Zens MS, Schned A, Andrew AS, Heaney J, Kelsey $K T$, Karagas MR: Analgesic and anti-inflammatory drug use and risk of bladder cancer: a population based case control study. BMC Urol 2007, 7:13.

39. Karagas MR, Stukel TA, Morris JS, Tosteson TD, Weiss JE, Spencer SK, Greenberg ER: Skin cancer risk in relation to toenail arsenic concentrations in a US population-based case-control study. Am J Epidemiol 2001, 153:559-565.

40. Wallace K, Kelsey KT, Schned A, Morris JS, Andrew AS, Karagas MR: Selenium and risk of bladder cancer: a population-based case-control study. Cancer Prev Res (Phila) 2009, 2:70-73.

41. Karagas MR, Nelson HH, Zens MS, Linet M, Stukel TA, Spencer S, Applebaum KM, Mott L, Mabuchi K: Squamous cell and basal cell carcinoma of the skin in relation to radiation therapy and potential modification of risk by sun exposure. Epidemiology 2007, 18:776-784.
42. Willett WC, Sampson L, Stampfer MJ, Rosner B, Bain C, Witschi J, Hennekens $\mathrm{CH}$, Speizer FE: Reproducibility and validity of a semiquantitative food frequency questionnaire. Am J Epidemiol 1985, 122:51-65.

43. Salvini S, Hunger DJ, Sampson L, Stampfer MJ, Colditz GA, Rosner B, Willett WC: Food-based validation of a dietary questionnaire: the effects of week-to-week variation in food consumption. Int J Epidemiol 1989, 18:858-867.

44. Willett WC, Stampfer MJ, Colditz GA, Rosner BA, Hennekens CH, Speizer FE: Dietary fat and the risk of breast cancer. N Engl J Med 1987, 316:22-28.

45. Karagas MR, Tosteson TD, Blum J, Klaue B, Weiss JE, Stannard V, Spate V, Morris JS: Measurement of low levels of arsenic exposure: a comparison of water and toenail concentrations. Am J Epidemiol 2000, 152:84-90.

46. Rees JR, Sturup S, Chen C, Folt C, Karagas MR: Toenail mercury and dietary fish consumption. J Expo Sci Environ Epidemiol 2007, 17:25-30.

47. Cheng T, Morris J, Koirtyohann S, Spate V, Baskett C: Study of the correlation of trace elements in caprenters' toenails. J Radioanal NuCl 1995, 195:31-42

48. Willett W: Nutritional epidemiology. USA: Oxford University Press; 1998.

49. Lindberg AL, Ekström EC, Nermell B, Rahman M, Lönnerdal B, Persson LÅ, Vahter $M:$ Gender and age differences in the metabolism of inorganic arsenic in a highly exposed population in Bangladesh. Environ Res 2008, 106:110-120.

50. Tseng C: A review on environmental factors regulating arsenic methylation in humans. Toxicol Appl Pharmacol 2009, 235:338-350.

51. National Institutes of Health (NIH), National Heart, Lung, and Blood Institute: North American Association for the Study of Obesity. Bethesda, MD: The practical guide: Identification, evaluation, and treatment of overweight and obesity in adults; 2000.

52. Dabney A, Storey JD: Q-value: q-value estimation for false discovery rate control.: R package version 1.1; 2009 http://genomics.princeton.edu/ storeylab/qvalue/index.html.

53. Storey JD: The positive false discovery rate: A Bayesian interpretation and the q-value. Ann Stat 2003, 31:2013-2035

54. Food and Nutrition Board, Dietary Reference Intakes for Energy, Carbohydrate, Fiber, Fat, Fatty Acids, Cholesterol, Protein, and Amino Acids (Macronutrients). Washington, DC: National Academies Press; 2005.

55. Jacques PF, Selhub J, Bostom AG, Wilson PWF, Rosenberg $\Vdash H$ : The effect of folic acid fortification on plasma folate and total homocysteine concentrations. N Engl J Med 1999, 340:1449-1454.

56. Basu A, Mitra S, Chung J, Mazumder DNG, Ghosh N, Kalman D, von Ehrenstein OS, Steinmaus C, Liaw J, Smith AH: Creatinine, Diet, Micronutrients, and Arsenic Methylation in West Bengal, India. Environ Health Perspect 2011, 119:1308-1313.

57. Rahman MM, Rahman F, Sansom L, Naidu R, Schmidt O: Arsenic interactions with lipid particles containing iron. Environ Geochem Health 2009, 31:201-206.

58. Brody T: Nutritional biochemistry. San Diego, California: Academic; 1999

59. Soyland E, Funk J, Rajka G, Sandberg M, Thune P, Rustad L, Helland S, Middelfart K, Odu S, Falk ES, Solvoll K, Bjorneboe GA, Drevon CA: Effect of dietary supplementation with very-long-chain $\mathrm{n}-3$ fatty acids in patients with psoriasis. N Engl J Med 1993, 328:1812-1816.

60. Kaur G, Cameron-Smith D, Garg M, Sinclair AJ: Docosapentaenoic acid (22: 5n-3): a review of its biological effects. Prog Lipid Res 2010, 50:28-34.

61. Tao SSH, Bolger PM: Dietary arsenic intakes in the United States: FDA total diet study, September 1991-December 1996. Food Addit Contam Part A 1999, 16:465-472.

62. Schoof RA, Yost LJ, Eickhoff J, Crecelius EA, Cragin DW, Meacher DM, Menze DB: A market basket survey of inorganic arsenic in food. Food Chem Toxicol 1999, 37:839-846.

63. Taleshi MS, Edmonds JS, Goessler W, Ruiz-Chancho M, Raber G, Jensen KB, Francesconi KA: Arsenic-containing lipids are natural constituents of sashimi tuna. Environ Sci Technol 2010, 44:1478-1483.

64. Schmeisser E, Goessler W, Francesconi KA: Human metabolism of arsenolipids present in cod liver. Anal Bioanal Chem 2006, 385:367-376

65. Rumpler A, Edmonds JS, Katsu M, Jensen KB, Goessler W, Raber G, Gunnlaugsdottir $\mathrm{H}$, Francesconi KA: Arsenic-containing long-chain fatty acids in cod-liver oil: A result of biosynthetic infidelity?. Angew Chem Int Ed 2008, 47:2665-2667.

66. Taleshi MS, Jensen KB, Raber G, Edmonds JS, Gunnlaugsdottir $H_{\text {, }}$ Francesconi KA: Arsenic-containing hydrocarbons: natural compounds in oil from the fish capelin, Mallotus villosus. Chem Commun (Camb) 2008, 39:4706-4707 
67. Bao L, Shi H: Potential molecular mechanisms for combined toxicity of arsenic and alcohol. J Inorg Biochem 2010, 104:1229-1233.

68. Hopenhayn-Rich C, Biggs ML, Smith AH, Kalman DA, Moore LE: Methylation study of a population environmentally exposed to arsenic in drinking water. Environ Health Perspect 1996, 104:620-628.

69. Mason JB, Choi SW: Effects of alcohol on folate metabolism: implications for carcinogenesis. Alcohol 2005, 35:235-241.

70. Salmon A: IARC monographs on the Evaluation of Carcinogenic Risk of Chemicals to Humans. Br J Ind Med 1985, 42:214.

71. Fleckman P: Anatomy and physiology of the nail. Dermatol Clin 1985, 3:373-381.

72. Nichols T, Morris J, Mason M, Spate V, Baskett C, Cheng T, Tharp C, Scott J, Horsman T, Colbert J: The study of human nails as an intake monitor for arsenic using neutron activation analysis. J Radioanal Nucl 1998, 236:51-57.

73. Thompson FE, Subar AF: Dietary assessment methods in A. M. Coulston and C. J. Boushey, editors. Nutrition in the Prevention and Treatment of Disease. 2nd edition. Boston, MA: Academic; 2008:3-39.

74. Draper NR, Smith H: Applied Regression Analysis. 3rd edition. Canada: John Wiley \& Sons Inc; 1998.

doi:10.1186/1475-2891-11-45

Cite this article as: Gruber et al:: Associations between toenail arsenic concentration and dietary factors in a New Hampshire population.

Nutrition Journal 2012 11:45.

\section{Submit your next manuscript to BioMed Central and take full advantage of:}

- Convenient online submission

- Thorough peer review

- No space constraints or color figure charges

- Immediate publication on acceptance

- Inclusion in PubMed, CAS, Scopus and Google Scholar

- Research which is freely available for redistribution 